\title{
Inducible Plasmid-mediated Copper Resistance in Escherichia coli
}

\author{
By DUNCAN ROUCH, ${ }^{1}$ J. CAMAKARIS, ${ }^{1}$ B. T. O. LEE ${ }^{1 *}$ AND \\ R. K. J. LUKE ${ }^{2}$ \\ 1 Department of Genetics, University of Melbourne, Parkville, Victoria 3052, Australia \\ ${ }^{2}$ Department of Agriculture, La Trobe University, Bundoora, Victoria 3083, Australia
}

(Received 7 September 1984 ; revised 16 November 1984)

\begin{abstract}
The copper resistance in Escherichia coli determined by plasmid pRJ1004 is inducible. The level of resistance is proportional to the inducing dose of copper. The level of copper resistance in induced and uninduced cells changes with the growth phase of the culture. Induced resistant cells accumulate less copper than uninduced cells, so that reduced accumulation may be the mechanism of resistance. We propose that the inducible plasmid-coded copper resistance interacts with the normal metabolism of the cell to protect against toxic levels of copper while allowing continued operation of copper-dependent functions.
\end{abstract}

\section{INTRODUCTION}

Heavy metal resistance in micro-organisms can occur by a variety of mechanisms including physical sequestration, exclusion and/or efflux, or detoxification, which may be tandem with efflux (Summers \& Silver, 1978). For example, mercuric and organomercurial resistance involves enzymic cleavage to $\mathrm{Hg}^{2+}$ followed by the reduction of toxic $\mathrm{Hg}^{2+}$ to the less toxic and volatile $\mathrm{Hg}^{0}$ (Summers \& Silver, 1978; Silver, 1981). However, cadmium resistance in Staphylococcus aureus is not due to detoxification but to reduced accumulation of $\mathrm{Cd}^{2+}$ by plasmid-containing resistant cells as a result of an energy-dependent efflux process coded for by plasmid genes (Tynecka et al., 1981). An energy-dependent arsenate efflux is responsible for plasmid-mediated arsenate resistance in $S$. aureus and Escherichia coli (Silver \& Keach, 1982). The resistance can be plasmid-, chromosomally- or transposon-encoded and may be constitutive or inducible depending on the metal resistance studied.

There are few reports of copper resistance in micro-organisms. Foster (1977) showed that copper $\left(\right.$ as $\left.\mathrm{Cu}^{2+}\right)$ is excluded in Chlorella vulgaris by an unknown mechanism. Lutkenhaus (1977) showed that non-specific exclusion of copper and other metabolites is associated with a major outer-membrane protein in $E$. coli $\mathrm{B} / \mathrm{r}$ and $\mathrm{K} 12$. Lerch (1980) reported a copper metallothionein (MT) in Neurospora crassa, which apart from mediating copper tolerance by sequestering excess copper may fulfil other functions depending upon the amount of copper present. The copper tolerance is possibly inducible but no induction experiments were performed and no mutants isolated. MT is a low-molecular-weight protein which contains a large number of cysteine residues. It is involved in binding of heavy metals and has been reported in many species (Kagi \& Nordberg, 1979). It is usually inducible by heavy metals. The only report of an MT-like protein in prokaryotes is that of Olafson et al. (1980), who showed the presence of a heavy-metalinducible protein with properties similar to a eukaryotic MT in the cyanobacterium Synechococcus. Fogel \& Welch (1982) showed that tandem gene amplification mediates copper resistance in yeast, and Karin et al. (1984) showed that the resistance was inducible by copper and involved a low-molecular-weight copper-binding protein, copper chelatin.

Resistance to copper of clinical isolates of E. coli (Elek \& Higney, 1970), and of coliforms isolated from sewage (Koditschek \& Guyre, 1974; Varma et al., 1976), has been reported.

Abbreviations: LB, Luria broth; LA, Luria agar. 
However, the genetic basis for the copper resistance of these isolates was not investigated. Tetaz $\&$ Luke (1983) have shown a plasmid-determined resistance to copper among isolates of $E$. coli from piggery effluent, where animals were fed a diet supplemented with copper sulphate. The plasmid, designated pRJ1004, is conjugative, has a molecular weight of $78.0 \times 10^{6}$ and allows the standard test strain of $E$. coli to tolerate up to $20 \mathrm{mM}-\mathrm{CuSO}_{4}$ under conditions where the plasmid-free strain can tolerate no more than $4 \mathrm{~mm}-\mathrm{CuSO}_{4}$. A low-level plasmid-mediated copper tolerance has also been reported for the plasmid Rts 1 (Ishihara et al., 1978) but no genetic studies have been carried out with the system.

We are concerned with the mechanisms of copper resistance and copper transport and utilization in micro-organisms. This paper presents evidence that the copper resistance conferred by pRJ1004 is inducible in the presence of low levels of added copper. The potential levels of copper resistance in induced and uninduced plasmid-containing strains changed with the growth phase of the cells.

\section{METHODS}

Bacterial strains. E. coli K12 strains ED8739 (Borck et al., 1976; Wood, 1966) and ED8739(pRJ1004) have been described previously (Tetaz \& Luke, 1983).

Luria broth (LB) consisted of $1 \%$ (w/v) Tryptone (Oxoid), $0.5 \%(w / v)$ yeast extract (Oxoid), $1 \%(w / v) ~ N a C l$, $0.5 \%$ (w/v) glucose. Agar (Davis J3) was added (final concentration 2\%, w/v) to prepare Luria agar (LA). M9 medium was prepared following Miller (1972). Copper-containing media were prepared by adding appropriate amounts of $1.0 \mathrm{M}-\mathrm{CuSO}_{4}$ (as $\mathrm{CuSO}_{4} .5 \mathrm{H}_{2} \mathrm{O}$ ) and adjusting the $\mathrm{pH}$ to 7.5 with $\mathrm{NaOH}$ before autoclaving. ${ }^{64} \mathrm{CuCl}_{2}$ was obtained from the Australian Atomic Energy Commission, Sydney, Australia.

Induction. Induction of copper resistance was tested by diluting an overnight culture 1 in 20 into LB supplemented with a range of sub-inhibitory concentrations $(0.04 \mathrm{mM} \mathrm{to} 1.2 \mathrm{mM})$ of $\mathrm{CuSO}_{4}$. After incubation of the culture at $37^{\circ} \mathrm{C}$ for $100 \mathrm{~min}, \mathrm{LB}$ containing $24 \mathrm{mM}-\mathrm{CuSO}_{4}$ was added to give a final concentration of $12 \mathrm{mM}$ $\mathrm{CuSO}_{4}$. Growth was then monitored as optical density at $620 \mathrm{~nm}$ using a Bausch and Lomb Spectronic 20 spectrophotometer. Similar results were obtained after pregrowth in LB containing sub-inhibitory concentrations of $\mathrm{CuSO}_{4}$ for periods as short as $5 \mathrm{~min}$.

${ }^{64} \mathrm{Cu}$ accumulation. Cells were grown in $10 \mathrm{ml} \mathrm{LB}$, to $\mathrm{OD}_{620}=0.7$, with or without the addition of an inducing concentration of copper $\left(0.8 \mathrm{mM}^{-\mathrm{CuSO}}{ }_{4}\right)$. The cells were then sedimented by centrifugation, washed twice in $\mathrm{M} 9$ plus $100 \mu \mathrm{g}$ chloramphenicol ml-1 and resuspended in $5 \mathrm{ml} \mathrm{M9}$ plus $100 \mu \mathrm{g}$ chloramphenicol ml-1. After 40-60 min on ice, the suspensions were prewarmed to $37^{\circ} \mathrm{C}$ (approximately $3 \mathrm{~min}$ ) before the addition of ${ }^{64} \mathrm{Cu}$ $\left(227 \mathrm{kBq} \mathrm{ml}^{-1}\right)$ in $5 \mathrm{ml} \mathrm{M9}$ plus $100 \mu \mathrm{g}$ chloramphenicol ml-1. Samples $(0.5 \mathrm{ml})$ were taken after 20 and $40 \mathrm{~min}$ incubation at $37^{\circ} \mathrm{C}$, sedimented by centrifugation, washed twice in $0.85 \% \mathrm{NaCl}$ plus $1 \mathrm{~mm}$-EDTA, and resuspended in the same volume of $0.85 \% \mathrm{NaCl}$, and the radioactivity was counted in a LKB 1280 Ultragamma gamma counter. After counting, the samples were assayed for protein following Bradford (1976) (Bio-Rad).

Effect of diluent on the viability of induced copper-resistant cells. An overnight culture of ED8739 grown in $10 \mathrm{mM}-$ $\mathrm{CuSO}_{4}$ was diluted into $0.85 \%$ saline, $\mathrm{LB}$ or $\mathrm{LB}$ containing $10 \mathrm{mM}-\mathrm{CuSO}_{4}$ and was plated immediately. Samples $(0.1 \mathrm{ml})$ were plated on LA or LA supplemented with $9 \mathrm{mM}-\mathrm{CuSO}_{4}$ and the number of surviving colonies was determined after $48 \mathrm{~h}$ incubation at $37^{\circ} \mathrm{C}$.

Effect of growth phase on resistance level. An overnight culture of ED8739(pRJ1004) was diluted 1 in 100 into LB. At various stages of growth, survival was monitored by plating samples onto LA containing various concentrations of $\mathrm{CuSO}_{4}$. These samples were appropriately diluted so that an equivalent number of cells were plated in each case. Colonies were counted after $48 \mathrm{~h}$ incubation at $37^{\circ} \mathrm{C}$.

\section{RESULTS}

A culture of the plasmid-carrying copper-resistant strain ED8739(pRJ1004) grown from an inoculum of cells previously exposed to $0.4 \mathrm{mM}^{-\mathrm{CuSO}_{4}}$ showed only a slight lag in growth after the $\mathrm{CuSO}_{4}$ concentration was increased to $12 \mathrm{mM}$, whereas the same strain grown without added copper showed a $135 \mathrm{~min}$ lag in growth when the copper concentration was thus increased. In contrast, a culture of the non-plasmid-carrying control strain ED8739 showed no growth in $12 \mathrm{mM}^{-\mathrm{CuSO}_{4}}$ whether or not the cells had been previously exposed to $0.4 \mathrm{mM}-\mathrm{CuSO}_{4}$ (Fig. 1 ). This indicates that the copper resistance determined by the plasmid pRJ1004 is inducible at least by pregrowth at $0.4 \mathrm{~mm}-\mathrm{CuSO}_{4}$. It is possible that the apparent induction was due to selection of pre-existing amplified cells carrying multiple copies of the copper resistance determinant. However, this is unlikely because under the conditions used in these experiments it 


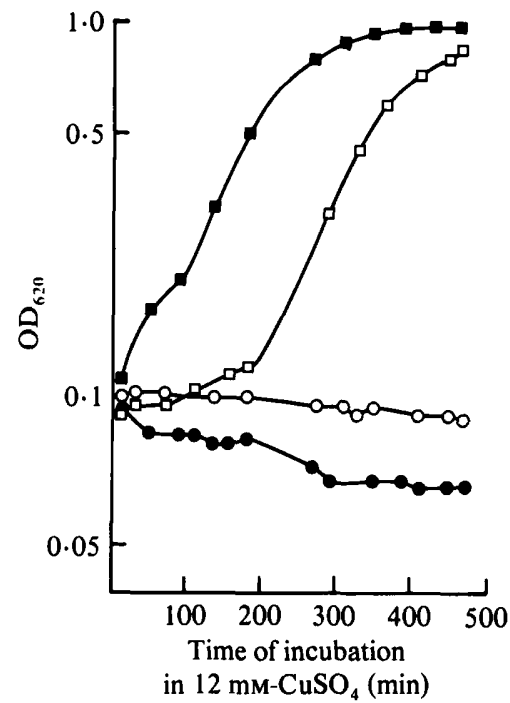

Fig. 1

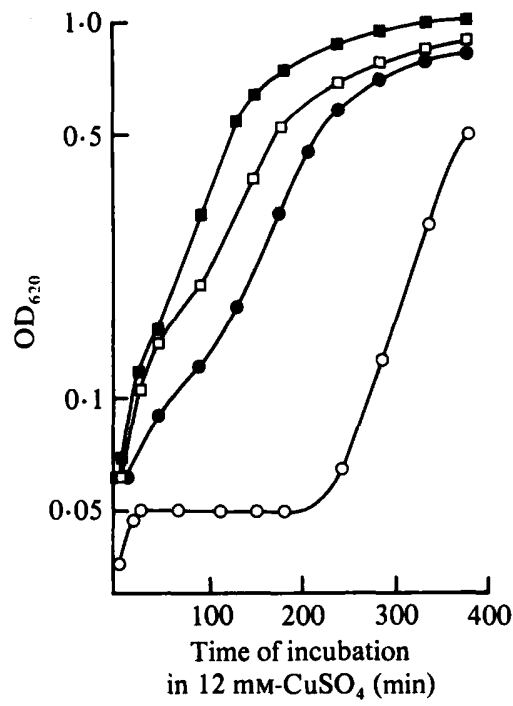

Fig. 2

Fig. 1. Growth $\left(\mathrm{OD}_{620}\right)$ of E. coli strains $\operatorname{ED8739}(O, O)$ and $\operatorname{ED8739}(\mathrm{pRJ} 1004)(\square, \square)$ in LB plus $12 \mathrm{mM}^{-\mathrm{CuSO}_{4}}$ after pregrowth in LB in the presence (filled symbols) or absence (open symbols) of $0.4 \mathrm{mM}^{-\mathrm{CuSO}_{4}}$ (representative results).

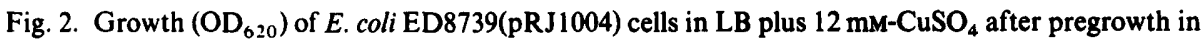
$\mathrm{LB}(\mathrm{O})$ or LB containing $0.04 \mathrm{mM}(\mathrm{O}), 0.4 \mathrm{mM}(\square)$ or $1.2 \mathrm{mM}(\square) \mathrm{CuSO}_{4}$ (representative results).

was possible to obtain a response in a previously unexposed population of cells after treatment with sub-inhibitory concentrations of $\mathrm{CuSO}_{4}$ for periods as short as $5 \mathrm{~min}$. Also, additional evidence (unpublished observations) suggests that when the copper resistance determinant is cloned into a high copy number plasmid, the resistant phenotype is not expressed.

Since the normal concentration of copper in LB is approximately $0.005 \mathrm{mM}$ (as measured by atomic absorption spectroscopy) and pregrowth in this medium resulted in a lag in growth of about $150 \mathrm{~min}$ after the concentration of $\mathrm{CuSO}_{4}$ was increased to $12 \mathrm{mM}$, it was of interest to determine whether the concentration of $\mathrm{CuSO}_{4}$ in the pregrowth medium affected the lag and the induction of resistance in the plasmid-containing copper-resistant strain. Cells were pregrown in $\mathrm{LB}$ containing various $\mathrm{CuSO}_{4}$ concentrations $(0,0.04,0.4,1.2 \mathrm{~mm})$ before the $\mathrm{CuSO}_{4}$ concentration was increased to $12 \mathrm{mM}$ (Fig. 2). The results indicate that within the range of concentrations tested, the greater the concentration of $\mathrm{CuSO}_{4}$ to which strain ED8739(pRJ1004) was exposed the shorter the lag in growth when the $\mathrm{CuSO}_{4}$ concentration was raised to $12 \mathrm{mM}$.

In an attempt to correlate optical density measurements with growth (viable counts) of ED8739(pRJ1004) we initially diluted in saline, cells which had been grown in LB plus 10 mM$\mathrm{CuSO}_{4}$. The results obtained were inconsistent with our estimates. We therefore tested the effects of different diluents and found that dilution in $\mathrm{LB}$ plus $10 \mathrm{mM}-\mathrm{CuSO}_{4}$ greatly increased viability compared to dilution in medium without added $\mathrm{CuSO}_{4}$. Viability after dilution in saline or $\mathrm{LB}$ was $2-4 \%$ of that after dilution in $\mathrm{LB}$ plus $10 \mathrm{~mm}-\mathrm{CuSO}_{4}$.

As we were also interested in the expression of copper resistance in relation to the phase of growth in medium containing no added $\mathrm{CuSO}_{4}$, survival and resistance of ED8739(pRJ1004) cells were assayed at various phases of growth and on various concentrations of $\mathrm{CuSO}_{4}$. Cells taken from cultures which had passed the mid exponential phase exhibited markedly greater copper resistance than did cells from younger cultures (Fig. 3). On plates containing more than $13 \mathrm{mM}^{-\mathrm{CuSO}_{4}}$, survival of late exponential phase cells $\left(\mathrm{OD}_{620}=0.7 ; 2.5 \times 10^{8}\right.$ cells ml$\left.{ }^{-1}\right)$ was 100 -fold better than was survival of early exponential phase cells $\left(O D_{620}=0 \cdot 2-0 \cdot 6\right)$. A similar result was also obtained with cells of this strain induced with $0.4 \mathrm{mM}_{-}-\mathrm{CuSO}_{4}$.

Typical results for the accumulation of ${ }^{64} \mathrm{Cu}$ by induced and uninduced cells of strain 


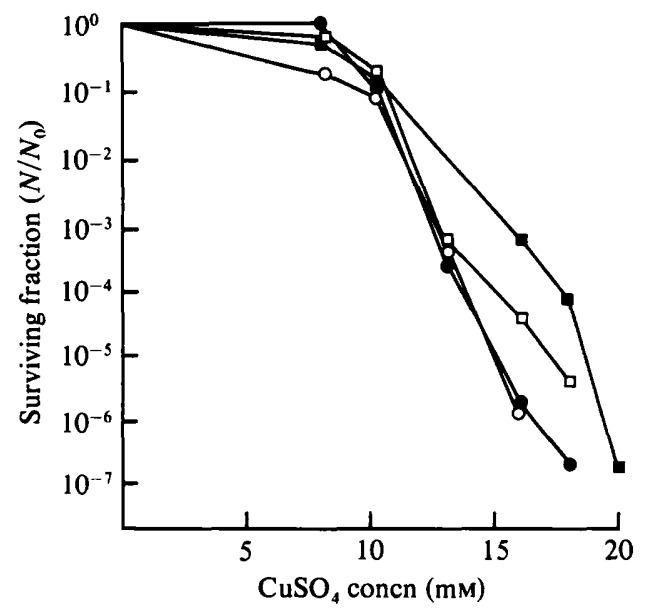

Fig. 3. Survival on various concentrations of $\mathrm{CuSO}_{4}$ of $E$. coli ED8739(pRJ1004) cells taken from cultures at different phases of growth: early exponential $\left(\mathrm{OD}_{620} 0 \cdot 2 ; \mathrm{O}\right)$; mid exponential $\left(\mathrm{OD}_{620} 0.5\right.$; ); late exponential $\left(\mathrm{OD}_{620} 0 \cdot 7 ; \square\right)$; and stationary $\left(\mathrm{OD}_{620} 1 \cdot 0 ; \square\right)$. (Representative results.)

Table $1 .{ }^{64} \mathrm{Cu}$ accumulation by E. coli strains ED8739 and ED8739(pRJ1004)

Cells were grown in minimal medium with or without pregrowth in minimal medium plus 0.8 mM-CuSO${ }_{4}$. Values are representative results.

\begin{tabular}{lccc}
\multicolumn{1}{c}{ Strain } & $\begin{array}{c}\text { Pregrowth with } \\
0.8 \mathrm{mM}^{-C u S O}{ }_{4}\end{array}$ & $\overbrace{20 \mathrm{~min}}^{\text {[c.p.m. }\left(\mu \text { protein }^{-1} \text { ] at: }\right.}$ \\
ED8739 & - & 1840 & $40 \mathrm{~min}$ \\
ED8739 & + & 1740 & 2736 \\
ED8739(pRJ1004) & - & 1780 & 1986 \\
ED8739(pRJ1004) & + & 540 & 1972
\end{tabular}

ED8739(pRJ1004) are shown in Table 1. When induced, the plasmid-containing strain has markedly reduced accumulation. Similar results were obtained in four separate experiments. However, because of differences in the specific activity of the ${ }^{64} \mathrm{Cu}$, different amounts of copper were added in each of the experiments and so the results cannot be pooled.

\section{DISCUSSION}

Although required in trace amounts for growth, at high concentrations copper is toxic to $E$. coli. $E$. coli cells must therefore be able to control the amount of copper they accumulate.

Our experiments indicate that copper resistance determined by plasmid pRJ1004 is inducible in the presence of as little as $0.04 \mathrm{~mm}-\mathrm{CuSO}_{4}$, and that (within the limits tested) the higher the concentration of $\mathrm{CuSO}_{4}$ to which the copper-resistant strain was exposed, the shorter the lag in growth when the $\mathrm{CuSO}_{4}$ concentration was subsequently raised to $12 \mathrm{mM}$. At $12 \mathrm{~mm}-\mathrm{CuSO}_{4}$ no growth of the plasmid-free strain occurs (Tetaz \& Luke, 1983).

The plasmid pRJ1004 confers a copper-resistant phenotype, the basis of which is reduced accumulation of copper under inducing conditions (Table 1). When copper concentrations are low, as they are in LB $(0.005 \mathrm{mM})$, constitutive expression of the copper resistance may prevent resistant (plasmid-carrying) cells from accumulating sufficient available copper to meet normal growth requirements. This may well explain the finding that the survival of maximally induced ED8739(pRJ1004) is decreased markedly when the cells are diluted in medium lacking added copper (unpublished observations).

The copper resistance mechanism encoded by plasmid pRJ1004 involves, we propose, an intracellular binding protein coupled with an efflux mechanism which ejects excess $\mathrm{Cu}^{2+}$. This system could function as a copper homeostasis mechanism which enables the resistant cells to 
tolerate concentrations of copper which are toxic to normal cells while still allowing operation of copper-dependent functions within the cell.

The potential levels of copper resistance in induced and uninduced plasmid-containing cells are markedly higher in late exponential and stationary phase than in early or mid exponential phase. Hempfling (1970) showed that oxidative phosphorylation in $E$. coli B growing in broth in early exponential phase was inefficient, but became more coupled in late exponential phase when glucose was exhausted. It is therefore possible that enhanced copper-resistance of late exponential phase cells is related to oxidative phosphorylation. Further work is required to determine whether resistance is energy dependent.

It appears that the copper resistance mechanism controlled by plasmid pRJ1004 is complex, and that we are dealing with a system in which one or more (inducible) plasmid-coded copper functions interact with the normal metabolism of the cell in a way which protects the cell against toxic concentrations of copper, while maintaining internal concentrations of copper which are adequate for the normal copper-dependent functions of the cell. The possible involvement of a specific copper-binding protein is being investigated.

This research was supported in part by a research and training grant from the Australian Institute of Nuclear Science and Engineering. We thank Tim Tetaz for advice, Neil Francis of the Birth Defects Research Institute, Royal Children's Hospital, for his help with atomic adsorption spectrometry and Joan Farrell for technical assistance.

\section{REFERENCES}

Borck, K., Beggs, J. D., Brammar, W. J., Hopkins, A. S. \& MURRAY, N. E. (1976). The construction in vitro of transducing derivates of phage lambda. Molecular and General Genetics 146, 199-207.

BraDFORD, M. M. (1976). A rapid and sensitive method for the quantitation of microgram quantities of protein utilizing the principle of protein-dye binding. Analytical Biochemistry 72, 248-254.

ELEK, S. D. \& HIGNEY, L. (1970). Resistogram typing a new epidemiological tool: application to Escherichia coli. Journal of Medical Microbiology 3, 103-110.

FoGel, S. \& WeLCH, J. W. (1982). Tandem gene amplification mediates copper resistance in yeast. Proceedings of the National Academy of Sciences of the United States of America 79, 5342-5346.

FOSTER, R. (1977). Copper exclusion as a mechanism of heavy metal tolerance in a green alga. Nature, London 269, 322-323.

Hempfling, W. P. (1970). Repression of oxidative phosphorylation in Escherichia coli by growth in glucose and other carbohydrates. Biochemical and Biophysical Research Communications 41, 9-15.

Ishinara, M., KAMID, Y. \& TeraWAKI, Y. (1978). Cupric ion resistance as a new genetic marker of a temperature sensitive R plasmid Rts 1 in Escherichia coli. Biochemical and Biophysical Research Communications 82, 74-80.

KAGI, J. H. R. \& NoRdBerg, M. (1979). Metallothionein. Basel: Birkhauser Verlag.

Karin, M., Najarian, R., Haslinger, A., Valenzuela, P., Welch, J. \& Fogel, S. (1984). Primary structure and transcription of an amplified genetic locus: the CUPI locus of yeast. Proceedings of the National Academy of Sciences of the United States of America 81, 337-341.

KoditscheK, L. K. \& GUYRE, P. (1974). Antimicrobial resistant coliforms in New York Bight. Marine Pollution Bulletin 5, 71-74.

LERCH, K. (1980). Copper metallothionein, a copper binding protein from Neurospora crassa. Nature, London 284, 368-370.
LUTKenhaus, J. F. (1977). Role of a major outer membrane protein in Escherichia coli. Journal of Bacteriology 131, 631-637.

Miller, J. H. (1972). Experiments in Molecular Genetics. Cold Spring Harbor, NY: Cold Spring Harbor Laboratory.

Olafson, R. W., Loya, S. \& SiM, R. G. (1980). Physiological parameters of prokaryotic metallothionein induction. Biochemical and Biophysical Research Communications 95, 1495-1503.

SILVER, S. (1981). Mechanisms of plasmid-determined heavy metal resistance. In Molecular Biology, Pathogenicity and Ecology of Bacterial Plasmids, pp. 179189. Edited by S. Levy, R. C. Clowes \& E. L. Koenig. New York: Plenum.

Silver, S. \& KEACH, D. (1982). Energy-dependent arsenate efflux : the mechanism of plasmid-mediated resistance. Proceedings of the National Academy of Sciences of the United States of America 79, 61146118.

Summers, A. O. \& Silver, S. (1978). Microbial transformation of metals. Annual Review of Microbiology 32, 637-672.

Tetaz, T. J. \& LukE, R. K. (1983). Plasmid controlled resistance to copper in Escherichia coli. Journal of Bacteriology 154, 1263-1268.

TYNeCKA, Z., Gos, Z. \& ZAJAC, J. (1981). Reduced cadmium transport determined by a resistance plasmid in Staphylococcus aureus. Journal of Bacteriology 147, 305-312.

Varma, M. M., Thomas, W. A. \& Prasad, C. (1976). Resistance to inorganic salts and antibiotics among sewage-borne Enterobacteriaceae and Achromobacteriaceae. Journal of Applied Bacteriology 41, 347349.

Wood, W. B. (1966). Host specificity of DNA produced by Escherichia coli: bacterial mutations affecting the restriction and modification of DNA. Journal of Molecular Biology 16, 118-133. 